\title{
Use of Bronze Celts in Military Operations
}

\author{
James Yates M.A., F.R.S.
}

To cite this article: James Yates M.A., F.R.S. (1849) Use of Bronze Celts in Military Operations, Archaeological Journal, 6:1, 363-392, DOI: 10.1080/00665983.1849.10850741

To link to this article: http://dx.doi.org/10.1080/00665983.1849.10850741

曲 Published online: 10 Jul 2014.

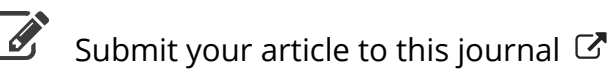

Q View related articles $₫$ 
incompatible with the abundance imported after the Norman conquest.

The only other church in which I have met with double splayed windows is that of All Saints, Melton Magna, which has quoinings of Roman shaped tiles, similar to those at Framlingham Pigot. ${ }^{3}$ I might mention besides, many other churches in which fragments of older buildings are retained, as at Tasburgh, North Walsham, Antingham, Swainsthorpe, East and. West Lexham, and other parishes. These will prove the justice of the observation of some old writer, whose name I do not remember, that our forefathers never rebuilt a church without preserving a portion of its predecessor.

USE OF BRONZE CELTS IN MILITARY OPERATIONS.

BY JAMES YATES, M.A., F.R.S.

Rend July 20th, 1849, at Salisbury.

THE design of the following remarks is to prove, that, among the various uses of bronze celts, one of the most important was the application of them in destroying fortifications and entrenchments, in making roads and earth-works, and in similar military operations. It will be observed, that I confine the inquiry to those celts which were made of bronze, and also to such as were adapted to be fitted to a straight wooden handle, and which belong to the fourth and fifth classes in Mr. Du Noyer's arrangement. ${ }^{1}$

I.-I shall first produce the passages of ancient Roman authors, which mention the application of dolabrce in the manner specified.

When Alexander the Great committed the rash act of leaping from the top of the wall into a city, which he was besieging, so as to put his life into extreme danger, some of his brave followers, "regardless of all peril, broke through

3 The church of St. John the Baptist, Cottishall, may be added, in which an ancient north wall remains with similar quoinings and herring-bone work of Roman-shaped bricks; and there are traces of a circular-headed door and two round windows above it, at present closed. Here also was $a$ church before the con- quest, and sepulchral urns, supposed to be Roman, are occasionally found. The use of such bricks in ecclesiastical buildings is not uncommon in localities which have been occupied by the Romans.

1 See Ârchaeological Journal, vol. iv,, pp. 2, 327.

On the subject of this memoir, I beg to 
the wall with chisels;" "periculi omnis immemores, dolabris perfregere murum" (Q. Curtius, ix. 5, [21, ed. Zumpt.]) They thus obtained access to their sovereign, and rescued him from the enemy. The operation is mentioned as one of great hardihood, because it was necessary to go close to the wall.

When Hannibal was besieging Sagunturn, he sent a detachment of five hundred men to destroy the wall from its foundation with chisels ; "quingentos ferme Afros cum dolabris ad subruendum ab imo murum mittit" (Livy, xxi. 11). On this single occasion it is to be observed, that some hundreds of chisels were employed for the destruction of the wall ; at least a sufficient number to employ five hundred men. The historian adds, that the work of destruction was easily effected, because, agreeably to an ancient practice, the stones of the wall were not cemented with mortar, but only joined by the interposition of mud or clay : "Nec erat difficile opus, quod cæmenta non calce durata erant, sed interlita luto, structuræ antiquæ genere." It is evident that the use of the chisels in this instance was to insert them between the stones so as to remove the clay or mud, and thus to displace the stones.

In another passage, where the same author is giving an account of the war between the Romans and Etruscans (ix. 37), he says, "Chisels were distributed among the calones, or servants, to throw down the mound and fill the ditches;" "Dolabræ calonibus dividuntur ad vallum proruendum fossasque implendas." The use of the chisels in this case must have been to loosen the stones and earth in the mound (vallum) as a preparation for filling the ditches. The attendants upon the Roman soldiers, who are called "calones," had the charge of these chisels. They are said to have borne this name from the Greek word kà $o v$, wood, because they carried wooden staves (clavas, see Festus s.v. Calones; fustes, Servius, in Virg. AEn. vi. 1); and the explanation which I have given shows, that these were essentially necessary to the use of celts or chisels in military operations. This second pas-

refer the reader to the article "DoLABRA," in the first edition of Dr. W. Smith's D:Ctionary of Greek and Roman Antiquities, in which I have produced evidence, first, to show that dolabra with its diminutive dolabella, and $\sigma \mu i \lambda \alpha$ with its diminutive $\sigma \mu l \lambda i o v$, meant a chisel or celt; and secondly, to illustrate some of the varioun uses to which, according to the testimony of ancient authors, these instruments were applied. 
sage of Livy also agrees with that already produced in showing what quantities of these instruments were taken on a military expedition in connexion with the engineering department. To the same effect is the inquiry of the general addressed to his soldiers in Tacitus (Hist. iii. 20.), "Num secures, dolabras, et cætera expugnandis urbibus secum attulissent?" i. e. "Whether they had brought with them hatchets, chisels, and the other instruments necessary for taking cities?"

There is another passage of Tacitus (Amn. III., 46), which is very instructive on account of the extraordinary manner, in which it represents the dolabræ to have been employed. It is, I believe, the only known case of the use of this implement in an attack upon persons. In Gaul, under the Emperor Tiberius, the Edui had revolted, and were led on by Julius Sacrovir, who occupied with his troops Augustodunum, now Autun, the principal city of the Adui. To increase the number of his forces, he availed himself of the assistance of those slaves, who were under training as gladiators, and who wore a complete suit of iron-plate armour. The javelins and swords of the Romans being ineffectual against this armour, they laid hold of their hatchets and chisels, as if they were breaking through a wall. With these they attacked the gladiators, cutting in pieces both the coverings and the covered. Some of them made use of thrusting-poles or forks, with which they threw down the inert mass of the enemy, and the gladiators, without attempting to rise from the ground, were left as if they were dead. "Paulum moræ attulere ferrati, restantibus laminis adversum pila et gladios: sed miles correptis securibus et dolabris, ut si murum perrumperet, cædere tegmina et corpora: quidam trudibus aut furcis inertem molem prosternere; jacentesque, nullo ad resurgendum nisu, quasi examimes linquebantur." In this passage, we have another proof that chisels and hatchets were among the usual accoutrements of the Roman army, and that they used them for breaking through walls. ${ }^{2}$

Juvenal mentions the use of the dolabra in making

In the collection of brouze celts belonging to the Society of Autiquaries of Picardy, preserved at Amiens, and also in that belonging to $M$. Boucher de Perthes, at Abbeville, I observed an implement, which is represented in the annexed wood-cut (size of the original) drawn partly from memory. It is hollow, in shape nearly cylindrical, and like a bottle. The upper part exactly resembles the celts of Mr. Du Noyer's 5th class, and is evidently intended to fusten 
encampments, when he is speaking of the humble condition of Marius as a soldier in his early days :

"Si lentus pigra muniret castra dolabra."-Sat. viii., 347 .

It has been justly remarked by Grangæus, one of the best commentators on Juvenal, that he does not here speak of the joiner's chisel, but refers to other works. A chisel, rough, strong, and blunt, in proportion to the nature of the work, was used by the ancients where we should use a pickaxe; and the stones, gravel, and soil, loosened by the chisel, were carried, not in wheel-barrows or waggons, as in our days, but in hand-barrows (alvei), or baskets (cophini).

Another very remarkable passage is the following anecdote preserved by Frontinus : "Domitius Corbulo dolabra, id est, operibus hostem vincendum esse dicebat."-Stratag. iv. 7, 2. By this maxim Domitius Corbulo, who was a most experienced general, intended to express his opinion, that the means of malking and destroying fortifications were more important in warfare than the use of the sword and the spear. Here I may observe, that the name Dolabella, which belonged

the bronze implement to a wooden handle.

But instead of having any edge or point,

this instrument terminates abruptly in a plane surface of a circular or oval shape. Its

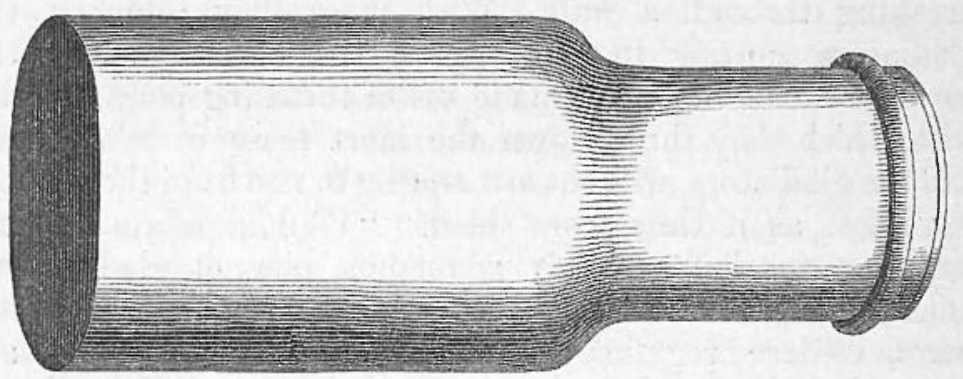

use is entirely a matter of conjecture. But I have little doubt that it belonged to the equipage of the camp. It has occurred to me, as the foregoing passage of Tacitus proves most clearly, that as the Roman soldiersused an implementcalled trudes, which was adapted merely to push or thrust, it may have been shod with the very thing which is here represented. So great was the care and nicety of the Roman soldiers in regard to their arms, that they would scarcely have used for any purpose even a wooden pole without some finish, or capping of metal. Whatever may be the value of this conjecture, antiquaries will be interested in the exhibition of this curious relic, which was found near Abbeville in 1847, and for the opportunity of representing which, I am indebted to the lindness of $\mathrm{M}$. Boucher de Perthes. I have seen an object of the same lind, but much smaller and flatter, in the fine collection of celts belonging to $\mathrm{T}$. Crofton Croker, Esq. Livy (xxviii. 3), in his account of the siege of Oringis, a city of Spain, says that both hatchets and chisels (secures dolabrceque) were used to destroy the gates; and he also mentions, that when the besiegers were scaling the walls, they were pushed down by forks, made for this express purpose (furcis ad idipsum factis detrudebantur). 
to a Roman family of great distinction, ${ }^{3}$ in all probability originated in the same practice. The first Roman who bore it, had achieved, we may suppose, some famous exploit in the capture of a city ; and hence, partly in jest, and partly in compliment, he was called the little chisel, "dolabella" being the diminutive of "dolabra," the common Latin name of this instrument.

In accordance with the expression of Livy, which proves that dolabræ were used to destroy an earth-work, we find from Vegetius, that the soldiers used them likewise in making roads: "Quod si angustæ sint viæ, sed tamen tutæ, melius est præcedere cum securibus ac dolabris milites, et cum labore vias aperire, quam in optimo itinere periculum sustinere." De Re Militari, iii. 6. ${ }^{4}$ This passage affords another proof that the ancients, although they were acquainted with

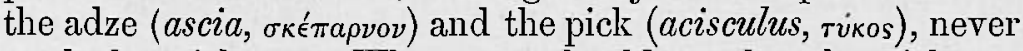
used the pick-axe. Where we should employ the pick-axe in overturning soil or loosening stones, they used the dolabra, or an agricultural implement, called bidens.

II.-The passages here cited have lately received a most remarkable illustration from the bas-reliefs brought to light by Dr. Layard among the ruins of the ancient edifices ${ }^{5}$ of Nimroud. In two of these bas-reliefs we see Assyrian soldiers performing the very act described by Curtius, "dolabris perfringentes murum," i. e., "breaking through a wall with chisels." See the annexed wood-cuts, copied from Plates XIX. and XXIX. of Layard's "Monuments of Nineveh," London, 1849. In both instances the wall, built of bricks or small stones, is destroyed by the use of chisels fixed at the end of staves; and in studying this representation, it must be borne in mind, that two soldiers, or even a single soldier, must be considered as representing a troop, just as a flock of sheep is in the same series of bas-reliefs expressed by

\footnotetext{
${ }^{3}$ No less than eleven persons of this family are mentioned in Roman history. See Smith's Dictionary of Greelc and Roman Birgraphy.

4 "It is better to send men forward with hatchets and other tools, to open ways that are narrow but safe, without regard to their labour, than to run any risk in the finest roads."-Militar'y Institutions of Vegetius, translated from the Latin by Lieutenant Joln Clarke, London, 1767.
}

This translator, not lnowing the sense of "dolabræ," has used for it the expression "other tools." For the same reason Philemon Holland, in his translation of Livy, has rendered the word "all manner of instruments."

5 These edifices are regarded by their enterprising and accomplished discoverer as palaces. I incline to the opinion that they were tombs. 
two or three sheep, and a company of horsemen perhaps by

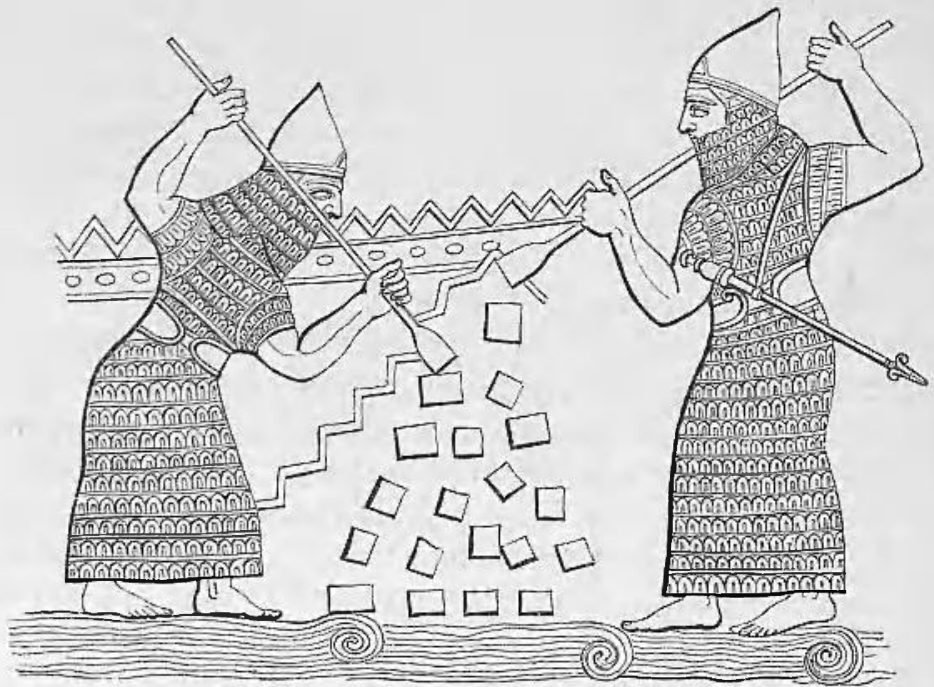

a single horseman. The slab, from which the upper woodcut is taken, is in the British Museum. ${ }^{6}$

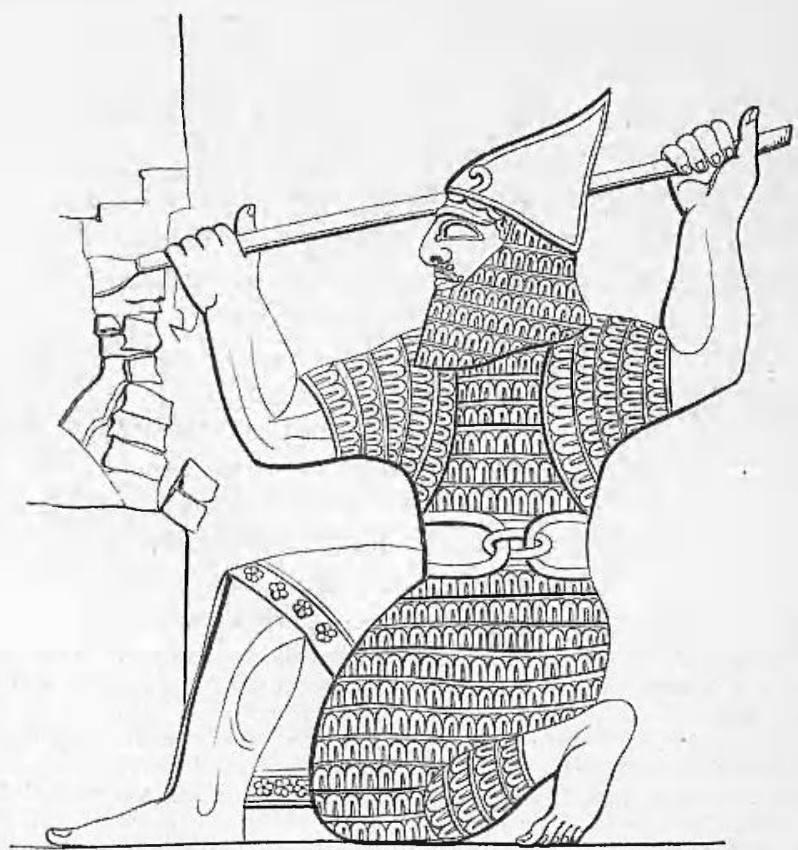

'In the Revue Archéologique, (vol. ii., p. 735, Paris, 1845,) is a figure and deseription of the remains of a cuirass found in Upper Egypt, which appears to have been made exactly in the same manner as the cuirasses worn by the three soldiers 
III.--Another recent discovery is that which has been already brought before the Archaeological Institute by my friend Mr. S. P. Pratt. 7 The Spanish celt, which he exhibited last January, has been presented by him to the British Museum. It is 18 centimetres ( $=7$ inches $)$ long, the blade alone being 12 centimetres; its edge is $4 \frac{1}{2}$ centimetres in breadth. It belongs to $\mathrm{Mr}$. Du Noyer's 4th class. It has a loop on each side, and by means of these loops it was, when first discovered, firmly attached by thongs to a straight handle of wood. On my asking Mr. Pratt whether the handle was straight or crooked, he said, that according to the information he had obtained, it was straight, the instrument having been fitted to be used as a crowbar, not as a hatchet. $^{8}$

In the annexed wood-cut this instrument is reduced to half its real dimensions. It will be observed, that it is slender compared with a great proportion of the celts found elsewhere. Indeed, many examples might be produced of bronze celts four or five times the weight of this, and at the same

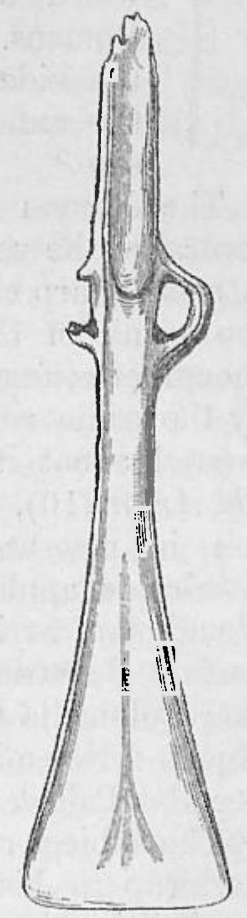
time better adapted by their form to act as levers or wedges. If, therefore, the celt brought to light by Mr. Pratt was large and strong enough to subvert natural strata of coal and sand-stone, many of those preserved in our museums must have sufficed, not only to destroy earth-works, but to loosen the courses of brick and stone in artificial fortifications.

IV.-If celts were used in mining, we cannot wonder that they should be employed also in digging, as well as in other operations connected with agriculture and gardening.

in the Assyrian bas-reliefs. This fragment consists of bronze scales or plates, in form precisely like those of the basreliefs, stitched upon leather. It bears the name of Sheshonk, the Shishak of Scripture. The warriors in Egyptian paintings sometimes wear the same cuirass. Dr. Layard found at Nimroud an iron helmet, the fragments of which are in the British Museum, and which was exactly like those worn by the three Assyrian soldiers.

- Archaeological Journal, vol. v., p. 69.

8 The remains of the stick were in one of three bronze celts with loops on the sides, which were found in one of the Irish Crannoges: Archlaeological Jou'nal, vol. iii., pp. 46,47 : likewise in some of those mentioned in Lord Ellesmere's "Guide to Northern, A rchaeology," London, 1848, p. 59. 
Some of the manuscripts of Hesiod's Works and Days contain drawings of the agricultural implements,

$\$$ which were in use among the ancient Greeks and Romans. They have their Greek names placed by the side of each, and the figure represented in the annexed woodcut, has the word $\sigma \mu i \lambda a$ by its side. ${ }^{9}$

The Roman writers on agriculture expressly mention several of the uses to which these instruments were applied. A small sharp chisel was used to cut out the dead wood from the trunk of the vine; an instrument of the same form, though of course much more blunt and rough, and yet called by the same name (dolabella), was employed to stir up the ground about its roots (Colum., De Re Rust. iv. 24, 26 ; De Arbor. 10). This tool was likewise used to refresh the soil in rose-beds (Pallad. iii. 21); and the same term, dolabra, is applied to the spud, or small spade, which the ploughman carried with him to destroy weeds. Hence the

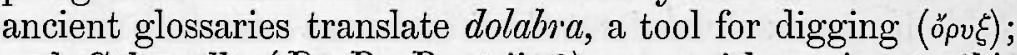
and Columella ( $D e R e$ Rust. ii. 2) says, with a view to this object, "Nec minus dolabra, quam vomere, bubulcus utatur." See also Pallad. ii. 3, "Glebæ dolabris dissipandæ."

The subject receives additional light from a remark of Mr. Sorterup in his "Descriptive Catalogue of the Northern Antiquities in the Copenhagen Museum" (Copenhagen, 1846). When he is speaking of those bronze celts, which he calls "Palstaves," and which belong to the fourth group in Mr. Du Noyer's classification, he mentions some which are broader and flatter than the rest, and says that they strongly resemble a tool which the Icelanders still use in the cultivation of their fields and gardens (p. 24). ${ }^{1}$ In other

\footnotetext{
${ }^{2}$ See Montfancon, Pal. Greca, p. 10 ; Hesiodi Opp. ed. Trincavelli, Venet. 15:7, p. exii. vers. and ed. Loesner, Lips. 1778, p. 342.

1 See also the "Guide to Northern Archacology," edited by the Earl of Ellesmere, London, 1848 , p. 60 . It is there stated that the so-called "palstaves," which were "shaped like a large chisel widened at the edge, and made to be inserted into a cleft handle which was made fast with a leathern band," "are still used under the same appellation in Iceland as a sort of pick or crow."

It is probable that when the Romans
}

used their celts in digging, they fixed a transverse bar of wood or metal into the base of the shaft, resembling the vangile, which the modern Italians use with their long spade, (vanga,) and on which the labourer places his foot in order to thrust the blade into the ground.

In cases where the Latins spoke of breaking through a wall, using the verbs perfringere, perrumpere, as in the above extracts from Curtius and Taritus, the Greeks and the Hebrews spoke of digging through it. See Thucyd. ii. 3 ; Æneas Tact. c. 32 ; Job, xxiv., 16; Ezek. viii. 8 , xii. $5,7,12$; Matt. vi. 19,20 , xxiv. 43 ; 
instances, and more especially in the continued use of the upright loom described by Homer, Virgil, and Ovid, ${ }^{2}$ we find ancient usages lingering in Iceland after they have been abandoned in all the rest of Europe. In like manner it appears that the Icelanders still use the dolabra in the cultivation of their fields and gardens, in accordance with the precepts of Columella and Palladius.

If, then, we have ample proof that these instruments were used in tilling the soil, we may the more readily admit their employment in any military operations, which required the same kind of manual labour.

V.-Another important circumstance in support of the same view is, that bronze celts of the required form are chiefly found about ancient encampments, and in various instances a great number have been discovered together. In the Isle of Anglesea a parcel was found under a stone near the spot where the Romans made their attack upon the Britons, under

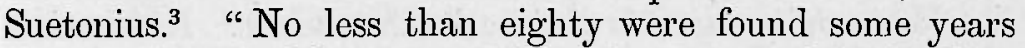
since in the parish of La Trinite, in Jersey." "In May, 1735 , there were found above one hundred on Easterley Moor, twelve miles north-west of York, together with several lumps of metal, and a quantity of cinders, so that no doubt remained of there having been a forge at that place for making them." "They have been found of the same form at Danbury and Fifield, in Essex, with a quantity of metal." 5 This is the well-known site of a Roman encampment. More than forty were found in 1726 in Hulne Park, near Alnwick Castle, with twenty swords and sixteen spearheads, of different patterns. ${ }^{6}$ At Reepham, in Norfolk, thirty were found in 174.7.7 A great number were found about the same time at a spot in the New Forest. ${ }^{8}$ The Count de Caylus has engraved one, which was found with twelve others under a stone twelve leagues from Paris, on the road from Versailles to Houdan. Some of them had never been used, as they retained "the seams of the mould" (les barbes du moule). The Count adds, that these instru-

Luke, xii. 39. The Greeks used the verb

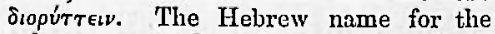
celt appears to have been מחרשה. See 1 Sam. xiii. 20.

2 See article "TeLA" in Smith's Dictionary of Greek and Roman Antiquities.

${ }^{3}$ Rowland, Mona Ant., pp. 85, 86.
4 Lukis, in Archaeol. Journal, vol. i, p. 226.

\footnotetext{
i Borlase, Ant. of Cornwall, pp. 283, 284.

6 Archaeologia, vol. v., p. 113.

7 Ibid, p. 114.

8 Ibid.
} 
ments are found all over France, being known by the name of "Gallic hatchets" (des haches Gauloises). ${ }^{9}$ At a much more recent period, M. Gerville has given an account of the quantities found in Normandy, which were so great, that the braziers sold them in abundance for old metal. He mentions more especially, that thirty bronze celts were found in 1820 at Chalendrey, in the arrondissement of Mortain, and that one hundred were discovered in an earthern vessel at Sainte-Croix, near Cherbourg. ${ }^{\text {? }}$

The instances now produced are sufficient to illustrate the fact, that the instruments in question are found in parcels, or considerable quantities, and in the vicinity of fortified places. They therefore obviously tend to illustrate the passages which I have quoted from Roman authors, and which refer to the use of dolabrce for martial purposes, and in large quantities at the same time.

VI.-I next argue in support of the same opinion from the size, form, and ornaments of the celts themselves. In this view of the subject we have to pay attention to their strength and ponderosity, their ornamental patterns, the loop or ring, found either on one side or on both, and their adaptation to be fitted to a wooden handle.

With respect to the mode of attaching the bronze celt to its handle, I am persuaded that it was commonly so done, that the instrument might be used, not as a hatchet, but as a spud, or a crow-bar. It was impelled, not to, but from the body of the workman, and the haft was consequently straight. At the time when this subject first came under discussion, Dr. Richard Richardson ${ }^{2}$ advanced the opinion that the haft was crooked, as represented in the figure annexed; and Mr. Du Noyer adopts the same view in his valuable essay "on the Classification of Bronze Celts." 3 To this opinion it has been objected, that we know perfectly well the form and construction of ancient hatchets, since many remain entire, and the representations of them in works of art, and antique monuments of all kinds, are innumerable. But in no case were metallic hatchets made with the crooked handle, which these modern authors have invented for them. Their form differs little, if at all, from

\footnotetext{
9 Recueil d'Anitiq, tom. ii., pp. 319, 320.

1 Mem. de la Soc. des Ant. de Normandie, 1828, p. 280.
}

2 See Leland's Itinerary, edited by Hearne, vol.i., p. 145.

3 Archaeol. Journal, vol. iv, pp. 5,6 . 
that of modern hatchets; nor can it be denied that these crooked handles would be apt to break at the elbow, nor that they were ill suited in general to their supposed purpose.

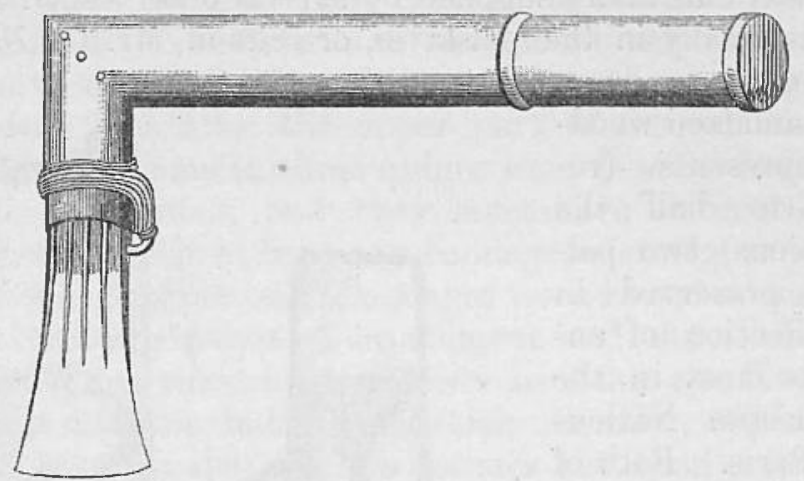

Examples have, indeed, been discovered in France, of small stone celts, so encased as to make a kind of hatchet. The celt is inserted into the bollow of a short piece of stag'shorn, and by means of a hole drilled through the upper part of the horn, a wooden haft is fixed transversely into it. ${ }^{4}$ But these primitive instruments would have very little power, and it cannot be supposed that, except in very rare cases, such a mode of making a bronze hatchet would have been resorted to among those who were well acquainted with the art of casting in metal, and were in the habit of making in the metal itself the transverse hole for the admission of the handle. Hence, notwithstanding these curious attempts at making hatchets of stag's-horn and fint, I entertain no doubt that the bronze celts, the use of which we are now considering, were generally used with straight handles, as represented in the Assyrian bas-reliefs (see above, p. 368), and exemplified in the Spanish, Irish, and Scandinavian implements already referred to.

This point being established, I proceed to observe that the wooden handle was attached to the metal in two ways. Either it was cleft so as to inclose the upper part of the celt, or it was cut into the shape of a wedge, so as to be inserted into it. In the former case the celt was of Mr. Du Noyer's

4 See Mem. de l'Acad. des Inscriptions, tome v., Paris, 1821, p. 71 . Mem. de la Soc. d'Emulation d'Ábbeville, 1835, p. 94,
-116. Mem. de la Soc. des Antiquaires du Département de la Somme (de Picardie), tome i., Amiens, 1838, p. 215-227. 
fourth class (see wood-cut, p. 369); in the latter case it belonged to his fifth.

Rivets having been used either rarely, or not at all, their place was effectually supplied by several other contrivances, more especially in the palstaves, or celts of Mr. Du Noyer's fourth class.

The annexed woodcut represents (reduced to half the dimensions) two palstaves preserved in the collection of ancient bronzes in the Bibliotheque Nationale at Paris. Both of them are thick and massive, but more especially that which is without a ring, and which is 2 decimetres ( $=7 \frac{7}{8}$ inches) long. On each are seen the two lateral ridges, which characterise all celts of this class; but in these specimens they are bent inwards, an appearance which is not of very frequent occurrence. It is seen, however, in two speci-
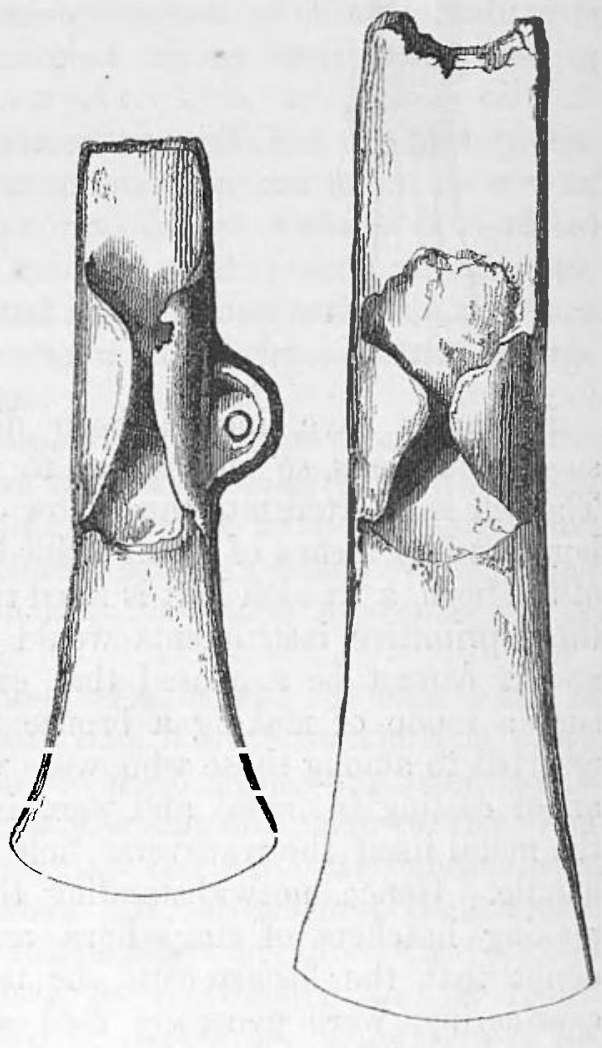
mens belonging to the collection in the British Museum, and in one of those found A.D. 1844, at Carleton Rode, in Norfolk. ${ }^{5}$

5 Archaeologia, vol. xxxi, p. 494. A fine example of this modification of the palstave is exhibited in the same work, vol. xvi., plate 68 . But in the collection of ancient bronzes at the Louvre in Paris, there is a palstave a bords recourbes, No. 2970 , no less than 24 centimetres $\left(=9 \frac{1}{2}\right.$ inches) long. It is massive and ponderous in proportion to its length, and has a round hole at the top instead of the usual ring at the side. There is another, No. 2971 , also with its lateral ridges bent invards, without any hole or ring, very strong, and 7 centimetres (= $2 \frac{3}{4}$ inches) broad at the edge. Another, No. 2968, which is 2 decimetres long, and has a small ring at the side, is no less than $11 \cdot 2$ centimetres ( $=4 \frac{1}{\circ}$ inches) broad at the edge. For the description of these three remarlable celts, all found in France, I am indebted to the lindness of $\mathrm{M}$. Adrien de Longperier, the Conservator of the Museum. 
In a discovery of various instruments and weapons at Notre Dame d'Or, in France, of which I shall hereafter make further mention, there were found eight celts of this kind (" haches a bords recourbés"), and also the half of a bronze mould for casting them. The cavities in the mould were deep in proportion to the projection of these extraordinary ridges. It is evident that, after the upper part of the celt had been placed in the handle, these ridges were beaten down upon it with a hammer, and they must have embraced it so tightly, that even without any bandage, a strong crowbar or lever would be produced. Bandages were, however, employed as the ordinary means of attachment, and those who have examined the modern stone celts used by the South Sea Islanders and the Indians of North America, will be at no loss to perceive that in this manner the handle might be fastened as firmly as possible. The annexed wood-cut is the imaginary section of a handle, designed to explain the manner in which the cleft or cavity of the handle was sometimes adapted to the wedge-shaped palstave. That palstaves were sometimes cast in this form is proved by a bronze mould intended for casting them, which is now in the British Museum, and of which I shall hereafter give an account. When the upper part of the palstave was inserted into this cavity, and the wood and bronze, so dove-tailed together, were tightly bound with cords or thongs, it is manifest that the two would be inseparable. They might be broken, but they could not be dislocated.

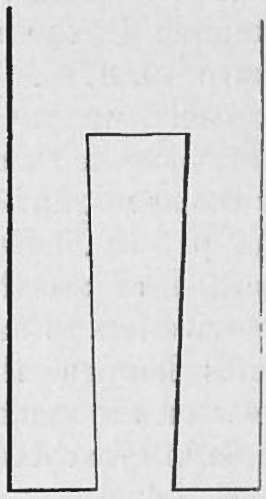

It has been supposed that the hollow celt of Mr. Du Noyer's fifth class was likewise attached to its handle by cords. (Sec the preceding wood-cut, p. 373.) Although there is the highest probability that this mode of attachment was often used in the case of these celts, as well as of palstaves, yet I have no doubt that another method was also adopted, which appears still more effectual. If I cut a stick, more especially of green wood, so as to adapt it to the socket of a celt, and dip it into water, the swelling of the wood will make it fill the celt so completely, that it will require very great force to separate them. If I wish to separate them, I have only to 
let them remain a day or two to dry, and the celt will then fall off by its own weight, in consequence of the shrinking of the wood. It is remarkable that these celts were never rivetted to the handle. Probably the rivet would have been an inconvenience. The principal use of the ring or loop, I apprehend, was to assist in carrying them, a dozen, or twenty, perhaps, being slung together, or a much smaller number tied to the soldier's belt or girdle. ${ }^{6}$ It appears likely that, when an army was on its march, the Calones often carried the chisels without staves, because these would be a useless encumbrance. They looked for a supply of staves to the natural wood, which they would not fail to meet with wherever their operations became necessary. Suppose, now, the dolabræ to be no longer wanted, they are left to dry, the bronze capping separates from the wooden handles, the celts are then slung as before, and the army proceeds on its march.

In some instances we observe that the ring is so small as to admit only a single cord or thong. Of this we have an example in the smaller of the two palstaves represented above (p. 374). In such cases the principal use of the ring, probably, was to assist in carrying the celt; but in many others the hole in the loop is much larger, so that the cord or thong might be passed through it many times (see woodcut, p. 369). Here it would be of greater service as a method of attachment. But, notwithstanding the various contrivances to fasten the celt to its handle, it would sometimes happen, that in destroying a wall a chisel thrust between the stones or bricks would be so firmly wedged, as to be in great danger of being detached from the haft, and

6 "As for the ears or loops, 'tis probable they might be put on, that thereby the handles might be fixt the better ; or perhaps they were designed for the ease of the soldiers, who in their journeys might by this means fasten them on their girdles." Thomas Hearne in Leland's Itinerary, vol. i., p. 132.

That the loop was used for the purpose of suspension, is, I think, proved by the discovery mentioned in the Archacoloria, vol. xvi., p. 362 , Plate LIV. A bronze ring is there engraved passing through a small ring or bead of jet and the loop of a hollow celt. These three articles were found near Tadcaster, exactly as they are represented in the engraving. They are now preserved in the British Museum. Mr. Du Noyer lias also given a representation of them in his memoir "On the Classification of Bronze Celts." (Archceed. Jonnal, vol. iv., p. 6). He supposes the ring to liave been used for the purpose of attaching the celt to the handle. But it is not suited to this purpose, inasmuch as it is a split ring, $i$. e., a piece of wire the ends of which, instead of being welded, soldered, or melted together, are only fitted together in sucl a way that the things to be suspended may be casily put on or taken off. It is, in fact, the lind of ring from which we often suspend our lieys. 
left in the wall. A thong or chain passed through the loop would in such cases afford the means of drawing it out again, and would prevent it from being lost. In the Mémoires de la Sociéte des Antiquaires de l'Ouest, Poitiers, A.D. 1844-1846, there is an account, as I am informed, of an ancient wall, in which celts were found sticking as if they had been left in this manner. It was supposed that they had been used instead of a ladder to scale the wall; but, if my theory is founded in fact, this will be regarded as a case in point; and it is evident that the loop or ring, having a cord or thong, or perhaps a chain passed through it, would be of great service to assist in withdrawing the celt.

This would be more especially the case where the celt was provided with two rings, as was often done. Through the kindness of our Secretary, Mr. Way, I am enabled to produce (half the real size) the figure in the annexed wood-cut of a bronze chisel, found A.D. 1810, in a barrow, near Pitcur, North Britain, and belonging to the collection of the Hon. James Talbot. It is very strong. Its lower end seems exactly fitted to act as a lever or a wedge. Its upper, bent perhaps accidentally, seems intended to be fixed in a

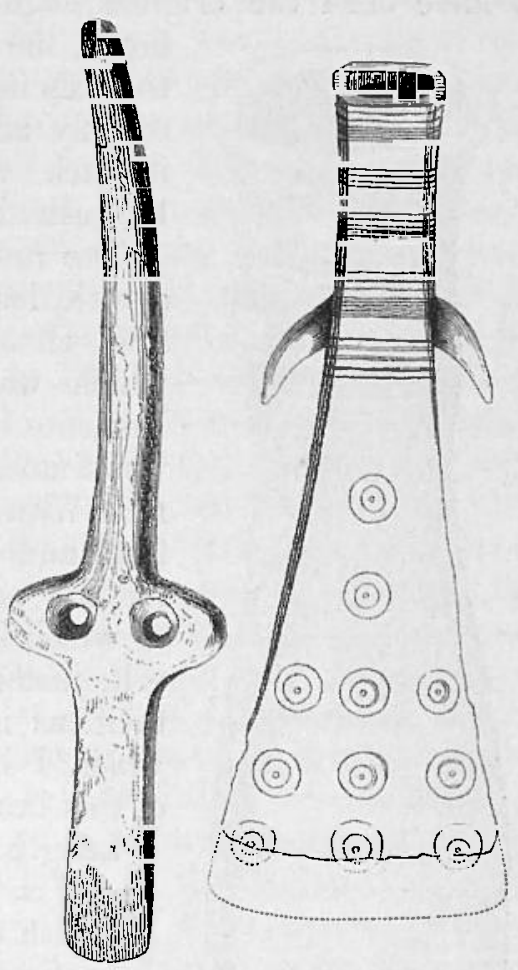
stout handle of wood, or possibly of horn, and the two rings would afford a very strong attachment either for fastening it to the handle, or withdrawing it from any fixed position. The circumstance of its discovery in a barrow is an evidence that it was used for some military purpose, for barrows were not the tombs of agriculturists, gardeners, masons, or carpenters, but of chieftains and warriors.

voL. VI. 
I also introduce in the same wood-cut the reduced representation of another remarkable form, which seems to be applicable in the same view of this subject. Count Caylus, to whom I have already referred for proofs that these implements are no less commonly found in France than in England, also informs us that they are to be reputed among the antiquities of Italy. ${ }^{7}$ Among seven, which he had obtained from Herculaneum, he describes and figures one of a remarkable form, which was 2 decimetres (nearly 8 inches) long, notwithstanding the abrasion of its edge. (See the wood-cut, in which I have represented by a dotted line what I suppose to have been the original edge.) It has on its sides two

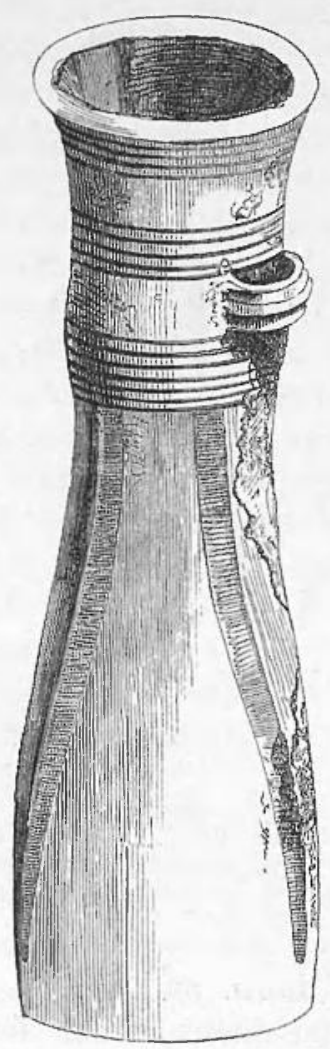
horns, the points of which are directed towards its edge. ${ }^{8}$ These horns seem exactly adapted to assist in drawing it back whenever it became fixed between the stones of a wall.

The annexed wood-cut represents, a little less than the original, a very fine celt of Mr. Du Noyer's fifth class, which was lately presented to this Institute by Mr. William English. It was found in the bed of the Thames near Wandsworth. Besides its elegant form and decoration, it is remarkable for the position of the loop, the bore of which is parallel to the axis of the celt, instead of being at right angles to it, as is the case in all other celts which I have seen. The dimensions of this beautiful object are as follows: Length of celt, 12 centimetres (= $4 \frac{3}{4}$ inches).

Width of its edge, 4.4 centimetres (= $1 \frac{3}{4}$ inches).

Diameter at the top, 3.7 centimetres (= $1 \frac{3}{8}$ inches).

- It has been asserted, that bronze celts are never found in Italy. I believe the occurrence of them in Italian cabinets is comparatively rare. But in confirmation of the statement of Caylus I may mention, that in the collection belonging to the Musee de $7^{\prime} A$ atillerie at Paris, there are five from Naples and one from Corsica. The celts in this collection, 25 or 26 in number, are all of the common form, i.e., belonging to Mr. Du Noyer's 4th and 5th classes.

8 Recueil d'Antiquites, tom. ii., Plate XCIV., fig. 2 , and pages $318,321,333$.

In the above-mentioned collection of 
In the year 1744 , several bronze celts, also of Mr. Du Noyer's fifth class, were dug up at Karn Bre, a very ancient fortification near the Land's End in Cornwall. With them were found a number of Roman coins, showing that these implements were probably in use among the Romans, and not among Gallic or northern nations only. Mr. Borlase, who gives this account, ${ }^{9}$ has engraved two of those which were found at Karn Bre. They are about 14 centimetres ( $=6$ inches) long, and the cavity designed to receive the handle is about 3 centimetres $\left(=1 \frac{1}{4}\right.$ inch $)$ wide, so that they were quite large and strong enough to be used in the manner which I have supposed. They present a good example of the ornamental mouldings, which in celts of this general pattern usually surround the socket, and on which Mr. Borlase founds the following argument. "If it shall appear," says he (p. 286), after observing how curious and elegant the ancients were about their arms, "that we have reason to reckon these celts among the weapons of war, it cannot be wondered at that they should be ornamented with mouldings, and embossed orderly-figured ridges." Thus far Borlase made an approach to the opinion which I wish to establish, but he concluded that these celts were the heads of spears, and thus fell into an error. Neither Borlase's conjecture that they were spear-heads, nor that of some other antiquaries, who have made them spear-tails, supposing them to have been intended to fix the spear into the ground, has met with any general acceptance. But, I think, the care bestowed in most cases upon their form and decoration, of which some examples may be seen in the preceding woodcuts, and in those of the former volumes of the Archaeological Journal, is agreeable to the habits of the military life of the ancients, no less than of modern times. There is a great variety in the patterns of the hollow celts more especially, and as much elegance of form as was possible in instruments, which were to be employed as spades, levers, and wedges.

VII.-In the same depositories with those bronze celts, which are the subject of the present investigation, there have often

celts belonging to the Bibliotheque $\mathrm{Na}$ tionale at Paris, I observed one exactly like that here copied from Caylus. It must have been either the same which he possessed, or cast from the same mould.
M. Muret told me, that, judging from the style of ornament, he believed this celt to be Gaulish, not Roman.

9 Antiquities of Cornwall, p. 281-283. Plate XXIV. 
been found not only celts of other forms, but also spear-heads, daggers, swords, and other military implements. ${ }^{1}$ This has been regarded as an indication, that the palstaves and hollow celts were also applied to martial uses. ${ }^{2}$

The first example which I shall produce in illustration of this argument, rests on the authority of Mr. Harford's "Account of Antiquities discovered in the Quantock Hills, A.D. 1794." 3 These antiquities were two tores and two celts, all of bronze. He gives an engraving, which shows their form and magnitude. One of the celts is 16 centimetres $\left(=6 \frac{1}{4}\right.$ inches) in length, its edge or lower extremity being 5 centimetres broad; and the whole implement must have been well adapted both as to size and strength for the removal of earth, and even for the destruction of walls. Such an implement might evidently be used in gardening and in agriculture agreeably to the remarks which I have already made. But the circumstance of the two torcs, which were in this instance found with the two celts, manifestly points to martial rather than to peaceful occupations. For the torc was a military decoration, and proves that these remains must have belonged to a soldier, and probably to one who had distinguished himself by his valour and ability in constructing camps, and in taking fortified places.

The armilla aurea was another decoration which the Roman generals bestowed as a reward upon their soldiers." We accordingly find, that "four bracelets of pure gold," belonging to the ring-money of our antiquaries, a spear-head, and three lumps of raw copper, were found in 1806 on the sea beach near Eastbourn in Sussex, together with five bronze celts, two of them having sockets for the handles, and the other three being palstaves with the lateral ridges bent inwards to embrace the handles as before described. ${ }^{5}$

I have already referred to the discovery made, A.D., 1844, at Notre Dame d'Or, in the department of Vienne. The articles of bronze, some entire and some broken, which were

1 See above, in $\S$ V. p. 371, the case near Alnwick Castle, and Archaeologia, vol. ix., pp. 84,85 .

" Da die genannten Sticlie neben einander liegen, so liefert dieser Fund don deutlichsten Beweis, dass neben den sogenaunten Celts auch schwertartige Lanzenspitzen, oder Dolche, in gebrauch waren."

'These are the words of the Rev. Ferdi- nand Keller, in describing the antiquities, viz. celts, spear-heads, swords, \&c., found in the Lalie of Zurich. See Mittheilungen der Antiquarien-Gesellschaft in Zurich, $1^{\text {ter }}$ Band, Zurich, 1844.

3 Archaeologia, vol. xiv., p. 94.

4 See Smith's Dictionary of Greek and Roman Antiquities, article ARM LIs.

5 Archacologia, vol. xvi., p. 363 , Plate LXVIII. 
found on that occasion in the vicinity of both Roman and Gallic constructions, included, besides the celts with borders bent inwards, and the half of a mould for casting them, celts (coins) of the hollow kind, spear-heads, swords, and daggers, and moreover a number of gouges like those used by joiners and cabinet-makers. ${ }^{6}$

In some of the instances which I have already quoted (See $\S \mathrm{V}$.), it has been argued from the fragments of bronze and lumps of metal, apparently designed for the meltingpot, that these were the remains of a bronze-foundry. An interesting discovery of this kind was made a few years ago near Amiens, and the objects brought to light, including celts of the usual forms, are carefully preserved and well displayed in that city as part of the museum belonging to the Society of the Antiquaries of Picardy.

For the account of another discovery, no less important, I am indebted to the kindness of the Rev. C. Wellbeloved, the Curator of Antiquities to the Yorkshire Philosophical Society. In the year 1845 a hoard of celts, very remarkable both for their number (more than fifty) and for the variety of their forms, was found at Westow, a village on the banks of the Derwent, in Yorkshire, not far from the site of the ancient Derventio. These articles are now preserved in the museum at York. Besides celts of the usual form, there were bronze chisels, resembling in shape those now commonly used, i.e. with a shoulder projecting all round at the top of the blade, and above this a strong spike made to be inserted into the wooden handle. There was also a mortice-chisel, the form and size of which are shown in the following woodcut. Its edge is only half a centimetre broad, so that it could only have been used to make mortices of a corresponding width ; it may therefore have been a joiner's or cabinet-maker's tool, although it might be useful in constructing military engines, or the furniture of a camp. It is hollow, and has no provision for a rivet. Of this there would be no need, because the strokes of the hammer would force the wooden handle downwards into it, so that the more it was used, the firmer would be its attachment to the handle. It is both well-formed and strong, and it must have been a very effective instrument. Other tools were discovered, which,

6See the aceount by M. Fillon, in "Mem. de la Soc. des Antiquaires de l'Oucsl,
roitien's, 1844," p. 465-481, and plate ix. 
as I am informed, were exactly like those now used for cutting leather. Another remarkable circumstance in this find at Westow was the number of gouges, which varied considerably in size. Two of them are here represented with the mortice-chisel, of the dimensions of the originals.
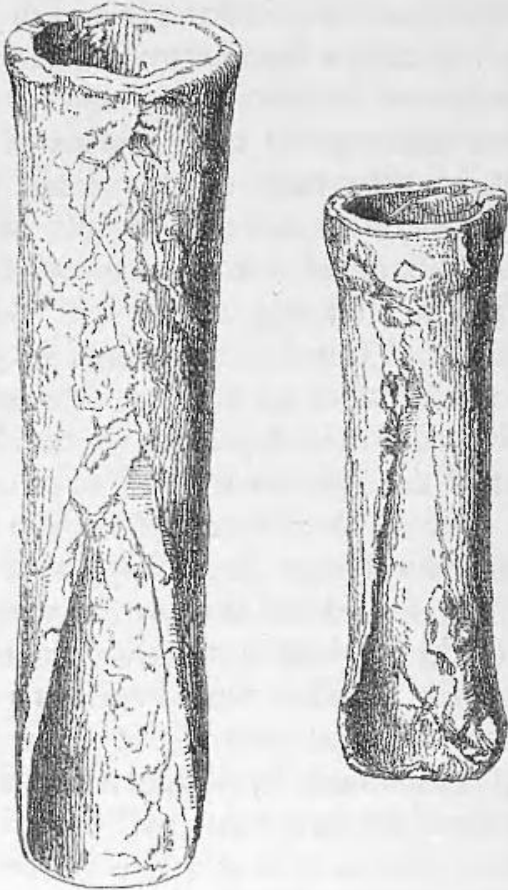

The edge of the gouges is bevelled on both sides, and differs in this respect from the modern gouge, the reason of which is, that in the modern manufacture a plate of steel is welded upon a plate of iron, and the one bevel is so adjusted that the steel always projects beyond the iron, and makes the cutting edge. In other respects, ancient bronze gouges resemble the modern instrument, being made hollow and adapted, like the mortice-chisel, to receive a wooden handle, without any rivet. With the celts, chisels, and gouges was found a fragment or small piece of bronze, which was evidently an overflowing of the metal from a mould.

Discoveries, similar to this at Westow, have been made at various places, both in England and in France. I may mention those at Carlton Rode and at Notre Dame d'Or, to 
which I have already referred. In such eases it would be absurd to pretend, that all the tools discovered were designed exclusively for martial purposes. A founder's workshop must be supposed to have furnished intruments to carpenters and other artificers, whether they were to be employed in times of war or of peace. But all the principal implements necessary for domestic purposes were also required in order to construct military engines, to raise or to destroy fortifications, and to make the furniture of the camp, We learn from Vegetius, ${ }^{7}$ that a legion was attended by carpenters, smiths, and other workmen, for making and repairing arms, carriages, equipages, canoes, wooden towers, and engines of all kinds for the defence and attack of fortified places ; and that it was furnished with chisels, hatchets, adzes, and saws (dolabrce, secures, ascice, serrce) for sawing, cutting, and planing wood; and with hoes, spades, shovels, rakes, hand-barrows, and baskets, for digging and removing earth. If we further bear in mind, that a Roman legion was stationed, for a long time, at the same place, instead of being often moved like an English regiment, ${ }^{8}$ we shall the more easily conceive how readily the engineers and artificers belonging to the legion might be employed, not only in making roads and bridges all over the country, but in the work of any neighbouring farm or villa.

Two sets of tools more especially deserve attention in connection with our present subject, viz. gouges and those used to cut leather.

Gouges were certainly employed to round and polish the shafts of arrows and of spears. This we learn from the following extract : ${ }^{9}$ " Ex parvissimis dolaturis, quales lancearum sive sagittarum hastas polientes faciunt." i.e. "Of the smallest shavings, such as are made by those who polish the shafts of lances or arrows."

- De Re Mil., 1. ii., c. 10, 11, and 25.

8 The Sixth Legion was established at York before A.D. 190, and had its head quarters there as long as the Roman power endured in Britrin (Wellbeloved's Eburacum, p. 34). The Twenty-first Legion was in like manner permanently settled in Switzerland (Schmidt, Antiquités de la Suisse, p. 49). Mr. Hermann Wiener, in his dissertation $D_{c}$ Lugione Romanorum Vicesima Sccunda, (Durnstadt, 1830), has proved, by collecting an abundance of evidence both from ancient authors and from bricks, pottery, and inscriptions on stone, that the twentysecond legion was employed in Germsny from A.D. 68 to A.D. 305. In fact, a legion was attached to a particular district almost like a colony or a corporation; and hence arose the immense intluence of the Roman occupation upon the manners and habits of the natives.

- Adelung, Glossarium Med. et Inf. Lat., tom. iii. p. 183. 
The celts adapted for cutting leather have an equal claim to be regarded as military implements ; for hides, both untanned and made into leather, were no less useful in the army than wood and bronze. Immense droves of cattle were necessary for the sustenance of the soldiers ; and, after they had been slain, their skins were employed for clothing, armour, carriages, packing-cases, and in various other ways; but more especially, in connection with the subject which I am now discussing, they supplied the best and easiest method of attaching the celts or palstaves to their wooden handles by means of thongs. This may be the reason why hoards of celts often contain tools like those now used by leathercutters. The lower extremity of these tools, which forms the cutting edge, is remarkably broad, and it is curved like the arc of a circle. These celts were used either without a handle, or with a short one.

VIII.- The arguments advanced in the two last sections are confirmed by the appearances of the celt-moulds, which are sometimes found with the celts themselves, and which are either of stone or bronze.

1. Celt-moulds of Stone.-Besides a very fine collection of celts, our temporary museum (at Salisbury) contained two moulds, one of serpentine, the other of granite. That which is of serpentine was found in Dorsetshire, and was intended for casting spear-heads. The other, which is of granite, was found near Amesbury in Wiltshire, and is the property of the Rev. Edward Duke, F.S.A. Its shape is that of a four-sided prism, and the cavities, engraved on two of its sides, show that it was intended to cast celts of two sizes, but both belonging to Mr. Du Noyer's fifth class. It will be observed, that there must have been another prism agreeing with this so as to complete the mould.

A still more remarkable mould is that of hone-stone found in Anglesea, which is described and figured in the Archaeological Journal, vol. iii., p. 257 , and is also represented in the annexed wood-cut. Like that just mentioned, it is a four-sided prism; but it has cavities on all the four sides, three of them being formed for casting the heads of spears or darts, and the fourth for casting hollow celts. Here we have a manifest indication, that the soldiers who used the spears or darts, also used the celts. At the same time this mould was well adapted to be carried on military expedi- 
tions, since, though it consisted of two pieces, each about 23 centimetres $(9 \cdot 14$ inches) long by 5 centimetres broad, it was

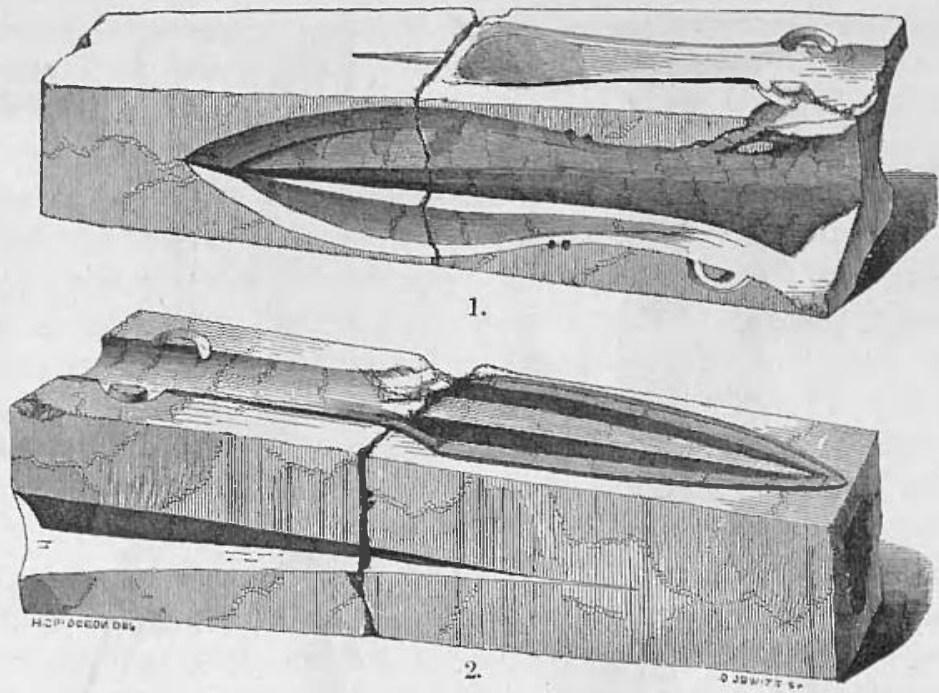

only necessary to place the different sides in apposition, in order to form moulds of four different kinds.

2. Celt-moulds of Bronze.-The following woodcut (see next page) exhibits, reduced to half the dimensions of the original, the outside and inside of a bronze celt-mould, preserved in the British Museum. Except that found at Notre Dame d'Or, as already mentioned, it is the only mould with which I am acquainted designed to cast palstaves or celts of $\mathrm{Mr}$. Du Noyer's fourth class. The pattern on the outside, consisting of three acute-angled triangles, one within the other, is neat, though less elaborate than the ornament of some of the moulds for casting hollow celts. The two parallel ridges which project from the upper part, and the transverse ridge which unites them at the base, afford space for the cavities, which were designed to produce the corresponding ridges in the celt itself, the transverse ridge representing the "stopridge" of the celt. In the inside view we observe at the top an hemispherical cavity, into which the metal was poured. Immediately below this cup-like cavity, and between the two parallel cavities designed to form the lateral ridges of the celt, we see a portion of the mould occupying the same space which would be occupied in the manufactured celt by voL. vI. 
one side of the cleft wooden handle. Here we observe the contrivance which I endeavoured to illustrate by the diagram
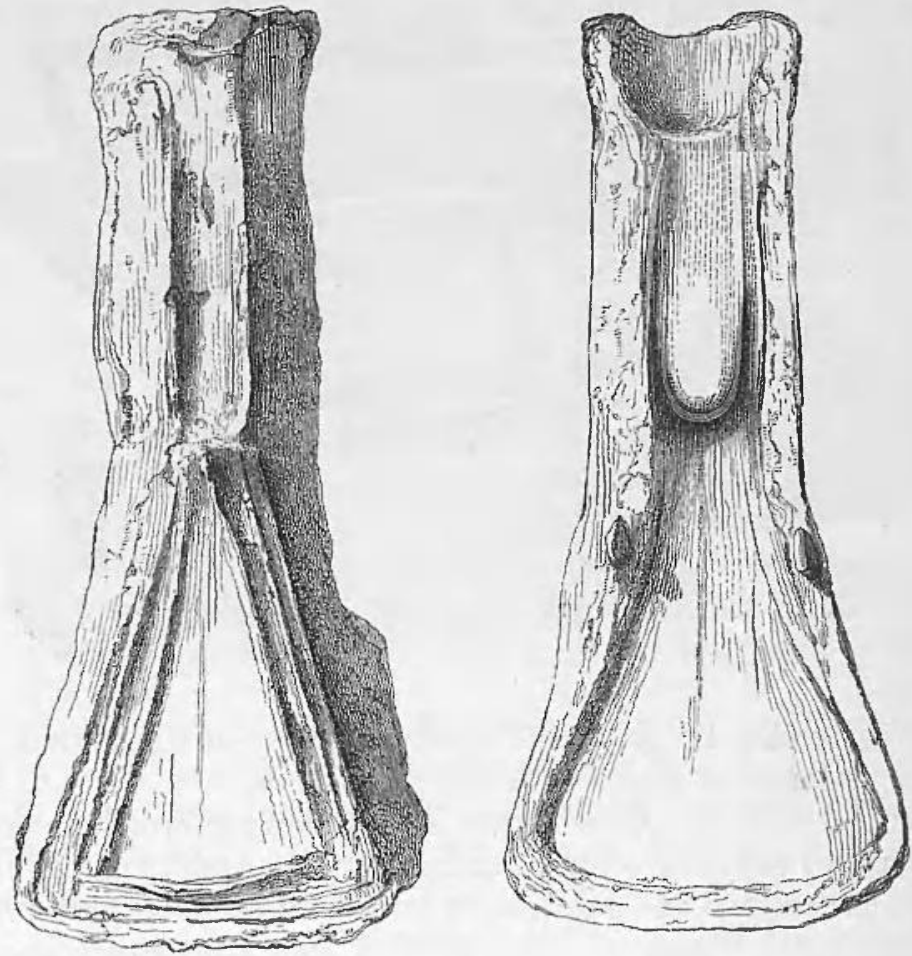

in $\$$ VI., p. 375. The upper part of the celt, destined to be inserted into the cleft handle, would be slightly contracted from above downwards, so that, when the celt and its handle were bound together, they would be inseparable. We next observe two notches or tenons on the two sides and a little below the middle of the mould, which are fitted to two mortices in the other half, and are designed to assist in keeping the two halves in their proper position. No provision is here made for decorating the blade of the celt. We perceive only a longitudinal ridge, which would tend in a slight degree to strengthen it. The celts cast in this mould would be large and strong enough for all the uses, of which mention is made in this memoir.

With the mould which I have now described, we may contrast that mentioned in the Archaeologia, vol. xxii., p. 424 
which was formed to cast socketed or hollow celts. Its external form and decoration, and likewise its internal appearance, are exhibited on a much reduced scale in the annexed wood-cut. It has a loop on each side, which would
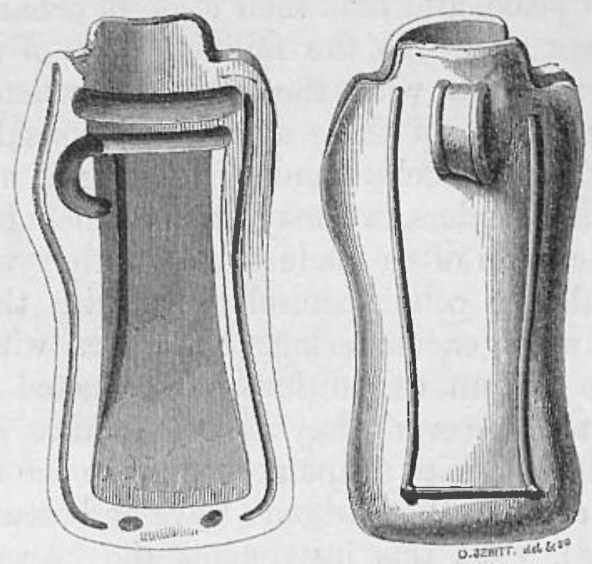

serve both to assist in carrying and suspending it, and also in tying the two halves together, when it was used for casting celts. In the inside of the one half are seen two lateral ridges, and at the bottom two notches or tenons. The woodcut shows in the other half the two lateral channels and the two oval mortices, which are fitted to rcceive the ridges and the tenons. Provision is made for a loop on one side of the celts. The length of the mould is 15.5 centimetres (= $=5 \frac{3}{8}$ in.), the length of the cavity for the celts to be manufactured from it, 11 centimetres. The fragments of celts, spear-heads, \&c., found with it were probably designed for the melting-pot. The core, which was necessary to make the socket of the celts, has not been found. This fine sample of the apparatus of a Roman ararius belongs to Clement Unthank, Essq., of Norwich, who has kindly entrusted it to me for examination.

But of all the moulds designed for casting hollow celts, the most beautiful with which I am acquainted is Mr. Bartlett's, now forming part of the fine collection in the British Museum. It is well represented and described both in the Archaeologia, vol. v., p. 109, Plate VII., figs. 2, 3, 4, 5; and in the Archaeological Journal, vol. iv., p. 330, figs. 5, 6, 7, 8, where the pre- 
cise and clear account given by Mr. Du Noyer renders any further detail superfluous.

Respecting these moulds, it may be observed in general, that, besides being admirably fitted for casting, they are remarkably compact, and thus well adapted to be carried from place to place, and that their style of ornament, though simple, appears suited to the military taste of the Romans. When, in connection with the shape, excellent workmanship, and ornament of these moulds, we consider that they are found with the celts made from them, with lumps of metal and with cinders, we may safely conclude that those who used the celts often made them as they were wanted. They did with the celts themselves as with their handles. Instead of always encumbering themselves with a load to be carried on distant expeditions, they trusted to find supplies of metal wherever they might require it, and they cast it into the requisite shape according to the occasion.

IX.-One of the authors whom I have had occasion to quote (Mr. Harford), calls this instrument the "ignus fatuus of antiquaries." The name appears very appropriate. For, not to mention that celts sometimes occur in bogs, and resemble a flame in their various shapes, they have certainly led the unfortunate antiquary many a dance, and plunged him into many a quagmire. But although I have so long occupied the attention of the Society, I will now venture to exhibit this changeful implement under another form, before I bring my discourse to a conclusion.

Tacitus, in the passage above quoted, refers to other instruments besides hatchets (secures) and chisels (dolabras), which were used in taking cities. His "et ceter a" was no doubt intended by him to include the drill (terebra, Vitruv. $\mathrm{x} ., 12$ ), and this instrument is also included under the term celt by modern antiquaries. The use of it is explained by the Greek writers on the art of taking cities, viz., Athenæus, Apollodorus, and Philo. ${ }^{2}$ They inform us that the soldiers

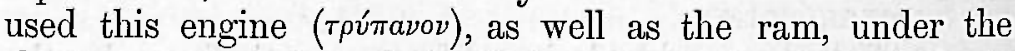
shelter of a testudo, and Apollodorus not only gives a minute account of its construction, but accompanies his description by two drawings for the sake of explanation. One of these is here copied (see wood-cut) as we find it in a MS. in the

1 Veteres Mathematici, ed. Thevenot. Par. 1693, pp. 4, 5, 18, 19, 92, 98. See also Aneas Tact. c. 32, Polyæn. vi. 3. 
British Museum (Cod. Burn. 69, f. 37) ; and although this MS. was written so late as A.D. 1545 , yet the author lived as

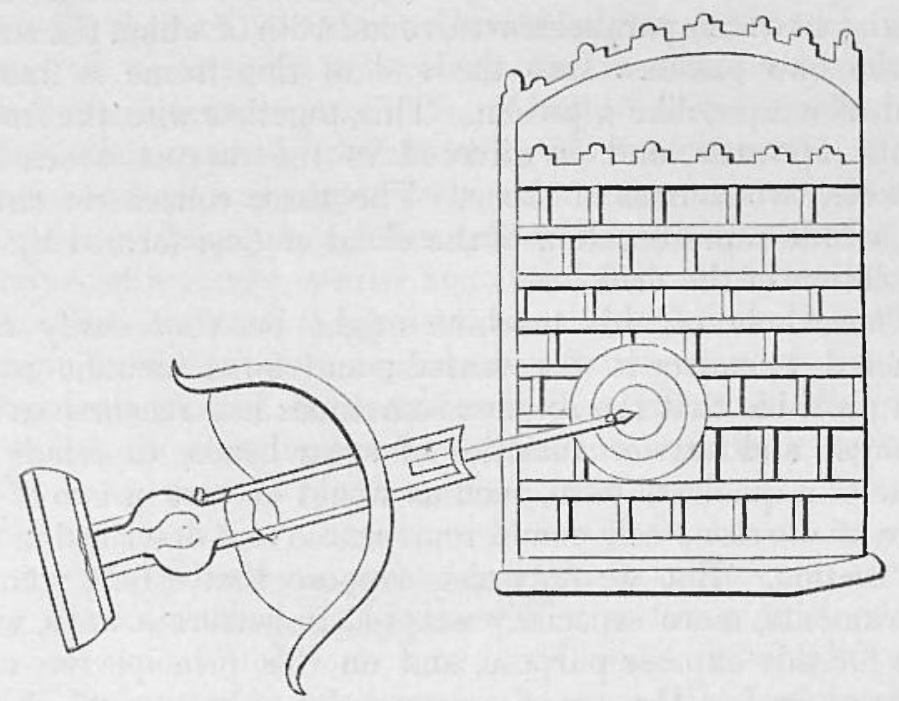

early as the time of the emperor Trajan, under whom he was extensively employed as a civil and military architect, and there is no reason to doubt that his drawings, made from machines, with which he was familiar, have been copied with sufficient accuracy in the MSS. of a much later date. We also find copies of these drawings in a Latin translation of the work published at Venice, A.D. $1572 ;^{2}$ in the Poliorcetica of Lipsius, Antwerp, 1596; and in the only edition of the Greek text which has yet appeared, published at Paris in 1693. From these drawings, as well as from the words of Apollodorus in the passage to which they relate, we learn that the drill was either simply turned by the hand, or was worked by means of a bow, or by the use of spoke-staves. It was commonly applied to the joint between the bricks or stones with the point slanting upwards, in order that the mortar, reduced to dust, might more readily fall to the ground, and it was moved from one part of the wall to another, as was deemed most effectual to the purpose.

The drawing, which is copied in the annexed wood-cut, appears to represent very faithfully all the essential parts of

${ }^{2}$ Heronis Liber de Machinis Bellicis, a Brrocio, Venet. 1572. 
this machine. It is that variety which was worked with a bow. We observe, first, a block of wood containing a pivot for the instrument to turn upon; then a wooden frame containing two long parallel staves, round both of which the string of the bow passes. Into the end of this frame is fixed a kind of weapon like a javelin. This, together with the frame, slants upwards and is directed to the mortar which lies between two courses of stone. The three concentric circles are a rude representation of the cloud of dust formed by the revolution of the drill.

The whole of this machine might be very easily constructed whenever it was wanted; and for a metallic point, it is probable that the soldiers sometimes had recourse to the stronger and heavier varieties of spear-heads, especially to those of a quadrate form, such as would be cast in two of the sides of the stone celt-mould represented and described in the last section. But we may also suppose that strong pointed instruments, more especially adapted to perforate walls, were cast for this express purpose, and on this principle we may perhaps explain the use of some articles of bronze, which are found and classed with celts, but to which no particular destination has hitherto been assigned. Of such objects I produce two examples.

One is the instrument found at Peel in the Isle of Man, which is represented in the Archaenlogical Journal, vol. ii.,

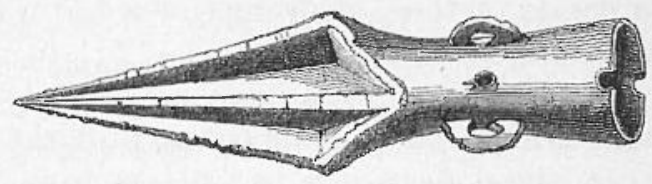

p. 187 , and repeated in the annexed wood-cut. It seems most exactly adapted to the purpose which I have supposed. Instead of the two edges of an ordinary spearhead, we see here four planes each with two edges, so that as the machine was turned backwards and forwards by the bow, four edges would rasp the brick, stone, or mortar in turning in one direction, and the four alternate edges would do the same in turning in the other direction. The comminuted materials of the wall would fall in powder through the four channels which separate the cutting edges. The instrument has a socket and loops for fastening it to 
the wooden shaft. It is 13 centimetres ( $=5$ inches) long. The eight cutting edges are apparently of equal dimensions and projection, and adapted to act with equal force upon the materials opposed to them. Indeed, in this interesting relic of ancient warfare, we see a remarkable union of symmetry with force, the workmanship being both fine and massive.

The other example is that of an instrument which is also pointed and of a quadrate form. It belonged to the Italian virtuoso and antiquary, Moscardo. In the account of his museum he has represented together two massive articles of bronze, one of which is a palstave with its lateral ridges bent inwards in the manner described in $\S$ VI. ; the other is the instrument, which I here exhibit with its dimensions greatly reduced. ${ }^{3}$ It is formed to be fastened to a wooden shaft by

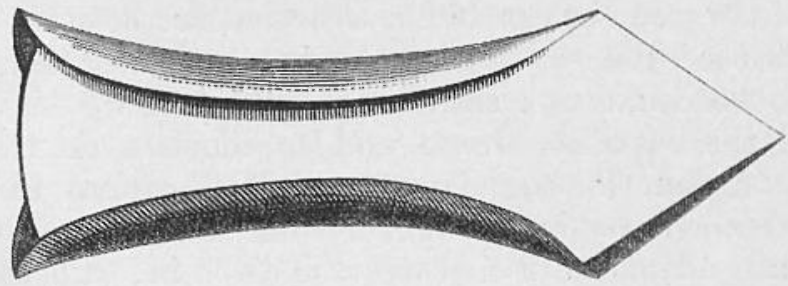

means of lateral ridges beaten down by the hammer as in the palstave; Moscardo inferred from the weight of these two implements, that they were intended to be thrown as great arrows from a catapult. But neither of them seems to me suited to this purpose, whereas that terminating in a point would have served very well as a drill to perforate walls.

I have introduced the subject of the drill both because our collections of bronze celts contain some articles which seem applicable to this purpose, and because in destroying walls the use of the drill was no doubt often subsidiary to the use of palstaves and hollow celts. When the wall was so close and compact that the celts could not be pushed between the courses, holes were drilled so as to make space for leverage, and the chisel was then wedged in and employed as a crowbar to loosen and displace the stones.

I have thus endeavoured to contribute my share towards the removal of what has been called the "opprobrium anti-

3 Note e figure del suo Museo, Padoa, 1656, p. $305:$ both figures are copied by

Lort, Archaeologia, vol. 5, p. 113, Plate VIII., 18. 
quariorum." Assuming that dolabra in Latin meant a chisel, I have proved by various direct testimonies the extensive use of this tool in ancient warfare. I have produced Assyrian sculptures in exact accordance with the words of Roman historians. From the use of the chisel in mining, in gardening, and in agriculture, I have shown its aptitude to be employed in military operations which required the same description of labour, that is to say, in making roads, mounds, and ditches, in mining and counter-mining, ${ }^{4}$ and in destroying both earth-works and walls of brick and stone. I have considered all the principal peculiarities in the various forms of the bronze celts of those classes to which I have confined my inquiry, and have shown that these peculiarities, together with the situations and circumstances in which the celts are found, support the same opinion. In short, wherever we should now use the spade, the crowbar, or the pickaxe, the ancients used the palstave or the hollow celt, fastened to a straight wooden shaft; and this was the practice not only of the Romans, but of the Greeks and Macedonians, the Hebrews. Assyrians, and Carthaginians, and of all nations to which they extended the knowledge of their arts, or which were sufficiently advanced in civilisation to dwell in fortified places.

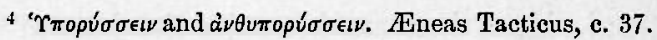

** The Central Committee desire to acknowledge the kindness of the Author, in presenting to the Society the numerous interesting Illustrations which accompany the foregoing Memoir. This unwonted contribution has appeared to justify a deviation, in the present Number, from the established rule, in regard to the limited extent of each Memoir given in the Journal. It has also seemed desirable to submit to our readers at one view the whole of the valuable examples, so carefully brought together from various countries, and for which they are indebted to the kind liberality of Mr. Y ${ }_{\Lambda T E S}$, in the promotion of Archaeological inquiry. 